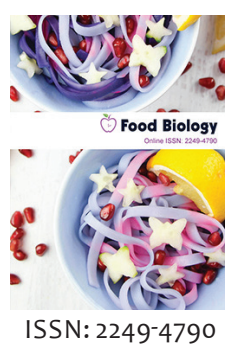

Received: April 11, 2018 Accepted: June 02, 2018 Published: June 14, 2018

*Corresponding Author: Qamar UI Hassan

Email: qamar1068@gmail.com

\section{Effect of different nutraceuticals on phytochemical and mineral composition as well as medicinal properties of home made mixed vegetable pickles}

\author{
Qamar UI Hassan ${ }^{1 *}$, Raja Adil Sarfraz² \\ 'Department of Chemistry, University of Agriculture, 38040 Faisalabad, Pakistan, ${ }^{2}$ Central Hi-Tech Laboratory, \\ University of Agriculture, 38040 Faisalabad, Pakistan
}

\section{ABSTRACT}

The present study was carried out to check the effect of different nutraceuticals on antioxidant activity, total phenolic contents, total flavonoid contents, antidiabetic activity, sensory evaluation and heavy metals of mixed vegetable pickles. The results were indicated that the $\mathrm{P} 3$ pickle sample which contained six medicinal plant powders showed the highest antioxidant activity $(87.56 \pm 0.02 \%)$, total phenolic contents $(77.12 \pm 0.01 \mathrm{mg} \mathrm{GAE} / \mathrm{l} 00 \mathrm{~g})$, total flavonoid contents $(14.67 \pm 0.06 Q \mathrm{QE} \mathrm{mg} / \mathrm{g})$ and antidiabetic activity $\left(\mathrm{IC}_{50}=25.89 \pm 0.07 \mu \mathrm{g} / \mathrm{mL}\right)$. The level of heavy metals was varied in all of the selected pickles but below permissible limit while according to consumer point of view all sample were accepted.

KEYWORDS: Nutraceuticals; mixed pickles; antioxidant activity; antidiabetic activity; heavy metals

\section{INTRODUCTION}

Pickling is the oldest and useful method which is used for the preservation of food by anaerobic fermentation or immersion in the vinegar and resulting food is called pickle. The word pickle is derived from Dutch language "pekel" which mean brine. Pickle is fermented food which contains various vegetables (beans, carrot, mango, green tomatoes, pepper, cabbage etc.) and spices while additives are added for the taste improvement. Sweet, vinegar, salt and oil pickles are very common commercial manufacture verities. Salt pickle contains fresh ana pure materials and salt; it is preserved with $12-15 \%$. Basically, lactic acid bacteria are used for the conversion of sugar into acid [1-3]. Salt plays main role in the fermentation process and is used to drawing out nutrients and water from the vegetables which are used as ingredients while salt is also used as substrate for the growth of lactic acid bacteria. In pickling process sugar is converted into acid (lactic acid) at acidic condition (approximately 4.6) and because of this acidic medium pathogen and aerobic spoilage microorganism's growth is inhibited. Due to pickling process texture and flavour of pickled vegetables are changed and after pickling show firm texture, translucent appearance and longer shelf-life [3-5]. Pickling process is used to preserve the vegetables for long time. Vinegar and vegetable oil is used as pickling medium in Asia [6]. Pickles contain phytochemicals and minerals which come from ingredients (Vegetables and spices), therefor pickles are useful against different diseases such as cancer, inflammation, brain dysfunction, atherosclerosis. The bioactive compounds are phenolic acids mostly flavonoids and tannins which scavenge the free radicals which are harmful for health and cause different diseases [7-9].

\section{MATERIALS AND METHODS}

\section{Chemicals and Ingredients}

DPPH (2,2-diphenyl-1-picrylhydrazyl), quercetin, ascorbic acid, gallic acid, perchloric acid, nitric acid, hydrogen peroxide, distilled water, 3, 5-dinitrossalicyclic acid (DNSA), folinciocalteu phenol reagent and all other chemicals and reagents which were used in all over the experiments were purchased from Merck (Darmstadt, Germany). All the chemicals used in research were of analytical grade.

\section{Collection and Preparation of Food Material}

Total four pickle samples were used in this study and samples were differentiate on the basis of medicinal plant powders. For the

Copyright: $\odot 2018$ The authors. This article is open access and licensed under the terms of the Creative Commons Attribution License (http://creativecommons.org/licenses/by/4.0/) which permits unrestricted, use, distribution and reproduction in any medium, or format for any purpose, even commercially provided the work is properly cited. Attribution - You must give appropriate credit, provide a link to the license, and indicate if changes were made. 
preparation of mixed vegetable pickles (carrot, green chili, lemon, bitter gourd and turnip), spices and mustard oil were purchased from local market of Faisalabad, Pakistan. While for value addition the plants (Solanum nagrium, Fogonia indica, Ocimum tenuiflorum Azadirachta indica, Mangifera indica and Moringa oleifera) were also collected from Faisalabad, Pakistan and these plants were confirmed by Department of Botany, University of Agriculture, Faisalabad, Pakistan. The pickle sample which contained (Solanum nagrium, Fogonia indica, and Ocimum tenuiflorum) grounded powders classified as $\mathrm{Pl}$, pickle sample which contained (Azadirachta indica, Mangifera indica and Moringa oleifera) grounded powders denoted by $\mathrm{P} 2$, pickle sample contained (Solanum nagrium, Fogonia indica, Ocimum tenuiflorum Azadirachta indica, Mangifera indica and Moringa oleifera) grounded powders classified as $\mathrm{P} 3$ while controlled was denoted by $\mathrm{P} 4$.

\section{Recipe and Formulations}

The mixed pickle samples were prepared by previously described assay with minor modification [5]. Firstly, vegetables were washed, peeled and trimmed into small pieces and added $3-4 \mathrm{~g}$ potassium meta bi-sulfite and this process is known as sulphiting. After that vegetables were cooked for different times at different temperatures like green chili was cooked for 4-5 minutes at $33-40^{\circ} \mathrm{C}$ and slices of carrots were cooked for 8-10 minutes at $40-50^{\circ} \mathrm{C}$ in hot water. The cooking process is known as blanching and this process is used for the inhibition of enzymatic activity. After that spices were added and again cooked for 2 minutes and then medicinal plant powders were added and further cooked for 6-8 minutes in mustered oil. The pickles were stored in the jar at $25^{\circ} \mathrm{C}$ until use. All the samples were prepared by the same way but differentiated only on the basis of medicinal plant powders.

\section{Analysis of Antioxidant Activity by DPPH free Radical Scavenging Assay}

The antioxidant activity of mixed pickle samples was determined by using DPPH free radical scavenging assay as previously described with minor modifications [10].

\section{Determination of Total Phenolic Contents}

The total phenolic contents were determined by folinciocalteu colorimetric assay as previously described with minor modifications [10].

\section{Determination of Total Flavonoid Contents}

Total flavonoid contents were determined by using aluminium chloride assay as described previously with minor modification [1].

\section{Alpha Amylase Inhibition Assay}

Alpha amylase inhibition assay was used to determine antidiabetic activity of mixed pickle samples as previously described [10].

\section{Determination of Heavy Metals By Wet Digestion Assay}

The heavy metals were determined in pickles by using wet digestion assay as previously described [11]. Briefly, lmL of each sample mixed with $10 \mathrm{~mL}$ of concentrated $\mathrm{HNO}_{3}$ and placed on a hot plate for 10 minutes at $60-70^{\circ} \mathrm{C}$. After that mixtures were cooled at room temperature and then added $5 \mathrm{~mL}$ of $\mathrm{HClO}_{4}$ and again mixtures were placed on the hot plate at $60-70^{\circ} \mathrm{C}$ until white fumes evolved and then mixtures were cooled at room temperature. After that $5 \mathrm{~mL} \mathrm{H}_{2} \mathrm{O}_{2}$ was added in each sample mixture and finally diluted by mixing distilled water on desired volume and results were determined by using atomic absorption spectrophotometer. The results were expressed in parts per million (ppm).

\section{Sensory Evaluation}

Total six panellists between 20-50 years from University of Agriculture Faisalabad, Pakistan participated in this study. Total 25-point hedonic scales were used for determination of sensory attributes of pickles [12].

\section{Statistical Analysis}

All analysis and tests were repeated three times and obtained results were expressed as mean \pm standard deviation. The analysis of variance was used to check significant difference in samples. Statistical significance was set at $\mathrm{p}<0.05$ [13].

\section{RESULTS AND DISCUSSION}

\section{Antioxidant Activity}

The antioxidant activity of value added mixed pickle samples was assessed by free radical scavenging assay. The values of antioxidant activity were lies in the range of $(87.56 \pm 0.02$ to $64.11 \pm 0.01 \%)$. The highest inhibition $(87.56 \pm 0.02 \%)$ against free radicals was shown by $\mathrm{P} 3$ sample while lowest inhibition $(64.11 \pm 0.01 \%)$ was observed in control. The ascorbic acid was used as standard found to be $(89.54 \pm 0.03 \%)$. The significant level was $\mathrm{p}<0.05$. The detailed results are shown in Table 1. The results were compared with previous findings whereby the range of antioxidant potential of leaf mustard pickle was reported as 37.25-85.36\%; while at 14-day preservation methanol extracts showed highest antioxidant activity $85.36 \%$ and ethanol extracts showed lowest antioxidant activity $37.25 \%$ at zero-day storage [13]. The present research provided interesting and very useful information that the mixed pickle which contained six medicinal plant powders (P3) showed excellent antioxidant potential as compared to others.

\section{Total Phenolic Contents}

The total phenolic contents were determined by folin-ciocalteu colorimetric assay which previously described. The total phenolic contents were lies in the range of $(77.12 \pm 0.01$ to 43.09 $\pm 0.05 \mathrm{mg}$ GAE $/ 100 \mathrm{~g})$. The highest phenolic contents $(77.12 \pm 0.01 \mathrm{mg}$ GAE$/ 100 \mathrm{~g})$ were found in P3 pickle sample 
while lowest phenolic contents (43.09 $\pm 0.05 \mathrm{mg} \mathrm{GAE} / 100 \mathrm{~g}$ ) were indicated by control. The details were discussed in Table 1. According to previous finding the results of phenolic contents of 10 vegetables pickles after 15 -day pickling were lies in the range of $12.23 \pm 0.98-64.25 \pm 7.31 \mathrm{mg} \mathrm{GAE} / 100 \mathrm{~g} \mathrm{FW}$. The total phenolic contents of cucumber, carrot, sneak melon, green beans, tomato, green paper, white cabbage, cauliflower and chili pepper was $12.23 \pm 0.98,14.18 \pm 1.32,15.36 \pm 1.25$, $18.32 \pm 2.11,20.02 \pm 2.15,20.98 \pm 3.41,48.25 \pm 6.82,49.56$ \pm 7.52 and $64.25 \pm 7.31$ respectively [5]. Our research provided motivating information about nutraceuticals and according to our results nutraceuticals are beneficial for human health and nutraceuticals gives much better results if mixed in pickles and nutraceuticals pickles are useful for consumers.

\section{Total Flavonoid Contents}

The total flavonoid contents were determined by aluminium chloride assay. The values of total flavonoid contents were in the range of $(77.12 \pm 0.01$ to $43.09 \pm 0.05 \mathrm{QE} \mathrm{mg} / \mathrm{g})$. The maximum total flavonoid contents $77.12 \pm 0.01 \mathrm{QE} \mathrm{mg} / \mathrm{g}$ were present in (P3) while lowest flavonoid contents $43.09 \pm$ $0.05 \mathrm{QE} \mathrm{mg/g}$ were observed in (control). The detailed results were discussed in Table 1. The results of research compared with previous literature. The leaf mustard pickle contained total flavonoid contents in range of $4.54 \pm 0.03-1.96 \pm 0.01$ QE mg/g. DLMP methanol extracts at 14-day storage indicated highest flavonoid contents $4.54 \pm 0.03 \mathrm{QE} \mathrm{mg/g}$ while lowest flavonoid contents $1.96 \pm 0.01 \mathrm{QE} \mathrm{mg/g}$ of DLMP ethanol extracts was at 0 -day storage [13]. The motivating information of research was that total flavonoid contents were increased by increasing the nutraceuticals in pickles.

\section{Antidiabetic Activity}

The antidiabetic activity was determined by alpha amylase assay and results were expressed by percentage inhibition. The values of inhibition were lies in the range of $\left(\mathrm{IC}_{50}=\right.$ $25.89 \pm 0.07$ to $11.67 \pm 0.06 \mu \mathrm{g} / \mathrm{mL}$ ). The highest inhibition
$\mathrm{IC}_{50}=25.89 \pm 0.07 \mu \mathrm{g} / \mathrm{mL}$ was observed by (P3) while lowest inhibition $\mathrm{IC}_{50}=11.67 \pm 0.06 \mu \mathrm{g} / \mathrm{mL}$ was indicated by (control). The acrobose was used as a standard found to $\left(\mathrm{IC}_{50}=31.26 \pm 0.05 \mu \mathrm{g} / \mathrm{mL}\right)$. The detailed results were shown in Table 2. According to the previous literature the antidiabetic activity of different solvent frictions of Heliotropium strigosum were lies in the range of $\mathrm{IC}_{50}=100 \pm 0.15$ to $10.45 \pm 0.01$ [10]. The informative fact of our research was that if different nutraceuticals were added then antidiabetic activity increased. So, Inhibition was directly related to the concentration of nutraceuticals.

\section{Sensory Evaluation}

According to sensory evaluation all pickles were accepted for use and all got score more than 50 out of 100 but $\mathrm{P} 3$ pickles which contained more nutraceuticals as compared to other samples were highly appreciated by consumers while Pl pickle was got minimum score from consumers as compared to other pickle samples. The detailed results were discussed in Table 2. According to the pervious findings the sensory evaluation of tomato seed oil was indicated that the tomato seed oil was highly appreciated by consumer if compared with control [14].

\section{Determination of Heavy metals}

The heavy metals were determined by wet digestion assay and results were expressed in parts per million (ppm). Total seven heavy metals ( $\mathrm{Pb}, \mathrm{Cd}, \mathrm{Zn}, \mathrm{Cu}, \mathrm{Fe}, \mathrm{Co}$ and $\mathrm{Ni}$ ) was analysed in home made pickles samples qualitatively and quantitively. The concentration of Lead $(\mathrm{Pb})$, cadmium $(\mathrm{Cd})$, zinc $(\mathrm{Zn})$ copper $(\mathrm{Cu})$ Iron $(\mathrm{Fe})$, cobalt $(\mathrm{Co})$ and nickel $(\mathrm{Ni})$ were $(0.23 \pm 0.02$ to $0.08 \pm 0.01 \mathrm{~mm}),(0.50 \pm 0.08$ to $0.18 \pm 0.03 \mathrm{~mm}),(27.12 \pm$ 0.01 to $19.09 \pm 0.05 \mathrm{~mm}),(27.84 \pm 0.01$ to $13.71 \pm 0.04 \mathrm{~mm})$, $(29.06 \pm 0.09$ to $18.46 \pm 0.01 \mathrm{~mm}),(23.55 \pm 0.03$ to 12.77 $\pm 0.04 \mathrm{~mm})$ and $(29.45 \pm 0.05$ to $18.21 \pm 0.01)$ respectively. The concentration of heavy metals in the pickles were below the permissible limit. The detailed results were discussed in

Table 1: Antioxidant activity, total phenolic contents, total flavonoid contents and antidiabetic activity of nutraceuticals pickles

\begin{tabular}{lcccc}
\hline Pickle samples & $\begin{array}{c}\text { Antioxidant } \\
\text { activity (\% inhibition) }\end{array}$ & $\begin{array}{c}\text { Total phenolic } \\
\text { contents }(\mathrm{mg} \mathrm{GAE} / 100 \mathrm{~g})\end{array}$ & $\begin{array}{c}\text { Total flavonoid } \\
\text { contents }(\mathrm{QE} \mathrm{mg} / \mathrm{g})\end{array}$ & $\begin{array}{c}\text { Antidiabetic activity } \\
\mathrm{IC} \mathrm{C}_{50}(\mu \mathrm{g} / \mathrm{mL})\end{array}$ \\
\hline P1 & $83.23^{\mathrm{c}} \pm 0.07$ & $56.12^{\mathrm{c}} \pm 0.04$ & $9.31^{\mathrm{b}} \pm 0.03$ & $19.00^{\mathrm{c}} \pm 0.09$ \\
P2 & $79.34^{\mathrm{b}} \pm 0.01$ & $52.40^{\mathrm{b}} \pm 0.09$ & $5.98^{\mathrm{c}} \pm 0.08$ & $15.29^{\mathrm{d}} \pm 0.02$ \\
P3 & $87.56^{\mathrm{a}} \pm 0.02$ & $77.12^{\mathrm{a}} \pm 0.01$ & $14.67^{\mathrm{a}} \pm 0.06$ & $25.89^{\mathrm{b}} \pm 0.07$ \\
Control & $64.11^{\mathrm{d}} \pm 0.01$ & $43.09^{\mathrm{d}} \pm 0.05$ & $2.31^{\mathrm{d}} \pm 0.08$ & $11.67^{\mathrm{e}} \pm 0.06$ \\
Standard & $89.54^{\mathrm{a}} \pm 0.03$ & -- & -- & $31.26^{\mathrm{a}} \pm 0.05$ \\
\hline
\end{tabular}

Standard for antioxidant activity: Ascorbic acid.

Standard for antibacterial activity: Acrobose

Table 2: Sensory evaluation of nutraceuticals mixed pickles

\begin{tabular}{lccccr}
\hline Pickle Samples & \multicolumn{5}{c}{ Sensory attributes } \\
\cline { 2 - 6 } & Odour(25) & Appearance(25) & Colour(25) & Taste(25) & Overall acceptability(25) \\
\hline P1 & $16.55^{\mathrm{c}} \pm 0.03$ & $16.76^{\mathrm{bc}} \pm 0.04$ & $13.76^{\mathrm{c}} \pm 0.01$ & $16.34^{\mathrm{c}} \pm 0.02$ & $73.44^{\mathrm{c}} \pm 0.01$ \\
P2 & $18.12^{\mathrm{b}} \pm 0.02$ & $17.00^{\mathrm{b}} \pm 0.01$ & $15.12^{\mathrm{b}} \pm 0.09$ & $19.63^{\mathrm{b}} \pm 0.08$ & $78.56^{\mathrm{b}} \pm 0.04$ \\
P3 & $21.67^{\mathrm{a}} \pm 0.07$ & $22.76^{\mathrm{a}} \pm 0.02$ & $18.92^{\mathrm{a}} \pm 0.02$ & $22.76^{\mathrm{a}} \pm 0.01$ & $83.65^{\mathrm{a}} \pm 0.02$ \\
Control & $11.56^{\mathrm{d}} \pm 0.01$ & $13.76^{\mathrm{c}} \pm 0.06$ & $12.89^{\mathrm{c}} \pm 0.04$ & $13.75^{\mathrm{d}} \pm 0.02$ & $68.12^{\mathrm{d}} \pm 0.01$ \\
\hline
\end{tabular}


Table 3: Concentration of heavy metals in mixed pickles

\begin{tabular}{|c|c|c|c|c|c|c|c|}
\hline \multirow[t]{2}{*}{ Pickle Samples } & \multicolumn{7}{|c|}{ Concentration in $\mathrm{ppm}$} \\
\hline & $\mathrm{Pb}$ & $\mathrm{Cd}$ & $\mathrm{Zn}$ & $\mathrm{Cu}$ & $\mathrm{Fe}$ & Co & $\mathrm{Ni}$ \\
\hline $\mathrm{Pl}$ & $0.08^{d} \pm 0.01$ & $0.50^{a} \pm 0.08$ & $22.89^{b} \pm 0.07$ & $19.27^{c} \pm 0.02$ & $29.06^{\mathrm{a}} \pm 0.09$ & $23.55^{\mathrm{a}} \pm 0.03$ & $26.98^{b} \pm 0.03$ \\
\hline P2 & $0.40^{c} \pm 0.03$ & $0.18^{d} \pm 0.03$ & $27.12^{\mathrm{a}} \pm 0.01$ & $27.84^{a} \pm 0.01$ & $27.24^{b} \pm 0.01$ & $18.76^{b} \pm 0.06$ & $23.78^{c} \pm 0.03$ \\
\hline P3 & $0.12^{b} \pm 0.09$ & $0.29^{c} \pm 0.01$ & $19.09^{c} \pm 0.05$ & $24.19^{b} \pm 0.09$ & $21.33^{c} \pm 0.03$ & $16.98^{c} \pm 0.09$ & $18.21^{d} \pm 0.01$ \\
\hline Control & $0.23^{\mathrm{a}} \pm 0.02$ & $0.42^{b} \pm 0.04$ & $21.11^{b c} \pm 0.02$ & $13.71^{d} \pm 0.04$ & $18.46^{d} \pm 0.01$ & $12.77^{d} \pm 0.04$ & $29.45^{a} \pm 0.05$ \\
\hline
\end{tabular}

Table 3. According to the previous finding the commercialized pickles purchased from local market of Bangladesh contained lead, zinc and copper below detection limit [2].

\section{CONCLUSION}

Our study to the best of our knowledge reported for first time to check the effect of nutraceuticals on antioxidant activity, total phenolic contents, total flavonoid contents, antidiabetic activity, sensory evaluation and heavy metal contents of mixed vegetable pickle. The results of our study showed that the mixed pickle which contained more medicinal plant powders showed excellent antioxidant activity, total phenolic and flavonoid contents, antidiabetic activity and sensory evaluation as compared to other while lowest potential observed in control which was did not contain nutraceuticals. So, our study suggested that the nutraceuticals are useful against different diseases and beneficial for use. The obtained sensory evaluation results were encouraging in terms of value addition of nutraceuticals.

\section{ACKNOWLEDGEMENTS}

We acknowledge staff of the Central Hi-Tech Laboratory, University of Agriculture, Faisalabad, Pakistan for their unprecedented cooperation for the completion of this research work.

\section{REFERENCES}

1. Nurul SR, Asmah R. Evaluation of antioxidant properties in fresh and pickled papaya International. Food research journal. 2012; 19: 1117-1124.

2. Rahman A. 2012. Assessment of quality and adulterants in selected commercial brands of pickle and chutney. Retrieved from http:// dspace.bau.edu.bd/handle/123456789/615.

3. Wikipedia. 2017. Pickling. Retrieved from https://en.wikipedia.org/ wiki/Pickling.

4. Karovicova J, Drdak M, Greif G, Hybenova E. The choice of strains of Lactobacillus species for the lactic acid fermentation of vegetable juices. European food research and technology. 1999; 210: 53-56.

5. Sayin FK, Alkan SB. The effect of pickling on total phenolic contents and antioxidant activity of 10 vegetables. Journal of food and health science. 2015: 1: 135-141.

6. Park BR, Park JJ, Hwang IG, Han HM, Shin MS, Shin DS, Yoo SM Quality and antioxidant activity characteristics during storage of tea leaf pickles with different vinegar contents. Korean j. food cook. Sci. 2014; 30: 402-411.

7. Pietta PG. Flavonoids as antioxidants. Journal of natural products. 2000; 63: 1035-1042.

8. Ganguli A, Ghosh M, Singh N. Antioxidant activities and total phenolics of pickles produced from the edible mushroom, agaricus bisporous. Journal of culinary science and technology. 2008: 5: $131-142$

9. Huang S, Huang M, Feng F. Antioxidant activity of extracts produced from pickled and dried mustard (brassica junceacoss. var. foliosabailey). International journal of food properties. 2012; 15: $374-384$

10. Qayyum A, Sarfraz RA, Ashraf A, Adil S. Phenolic composition and biological (anti diabetic and antioxidant) activities of different solvent extracts of an endemic plant (heliotropium strigosum). J. Chil. Chem. Soc. 2016; 61: 1.

11. Tuzena M, Soylak M. Evaluation of trace element contents in canned foods marketed from Turkey. Food Chemistry. 2007; 102: 1089-1095.

12. Sharoba AM, Senge B, El-Mansy HA, Bahlol HE, Blochwitz R. Chemical, sensory and rheological properties of some commercial German and Egyptian tomato ketchups. Eur food res technol. 2005; 220: 142-151.

13. Son HR, Oh SK, Choi MR. Total polyphenol, flavonoid contents and antioxidant activities of dolsan leaf mustard pickle during storage. Korean society for biotechnology and bioengineering journal. 2016; 31: 100-104.

14. Yilmaz E, Aydeniz B, Guneser O, Arsunar ES. Sensory and physico-chemical properties of cold press-produced tomato (Lycopersicon esculentum L.) seed oils. J am oil chem soc. 2015; 92: 833-842. 